\title{
Trends and Changes in Banking Sector of a Developing Country: The Case of Bangladesh
}

\author{
Nusrat Jahan ${ }^{1}$, Md. Asif Nawaz ${ }^{2}$ \\ ${ }^{1}$ Department of Business Administration, Uttara University, Uttara, Dhaka, Bangladesh \\ ${ }^{2}$ Department of Banking \& Insurance, University of Dhaka, Dhaka, Bangladesh
}

Email address:

jn.nusrat@gmail.com (N. Jahan), asif2511@yahoo.com (Md. A. Nawaz)

To cite this article:

Nusrat Jahan, Md. Asif Nawaz. Trends and Changes in Banking Sector of a Developing Country: The Case of Bangladesh. International Journal of Economics, Finance and Management Sciences. Vol. 4, No. 3, 2016, pp. 157-164. doi: 10.11648/j.ijefm.20160403.19

Received: May 11, 2016; Accepted: May 26, 2016; Published: June 7, 2016

\begin{abstract}
Economy of the world is being dominated by the banking industry. This industry has emerged since its birth. Today banking is known as innovative banking. This industry has gone through many changes. Journey of banking began with collection of money. And after all these years, banking industry has become an essential part of our lives. This paper deals with the changes and trends that have been experienced by banking industry. Today, banking services are not only limited to collecting deposits or lending money. We now enjoy services like E-banking, Investment banking, Islamic banking and so on. This paper focuses on the changes in the regulations of banking industry too. Banks has become a one stop shopping mall now. For this reason the term universal banking is invented.
\end{abstract}

Keywords: Trends in Banking, E-banking, Investment Banking, Islamic Banking, Changes in Regulation of Banking

\section{Introduction}

Banking sector is the key player of an economy. Since origin this sector has gone through many changes. People today are highly bankable. So there have been many changes and innovations in this sector. Many reforms have been made. Banking is now confined not only in retail banking. Shape of banking has been modified and to meet the demand of people E-banking, Islmaic banking etc have been invented. Banking products has been modernized and people are now enjoying so many banking products. This paper focuses on all the changes experienced by banking sector.

\section{Literature Review}

Financial sector reform has been initiated in so many countries in order to achieve the financial development. Important issue is now whether there exists any connection between the development and reform; and whether financial reforms in developing countries stimulate growth. Though several academic literature and empirical studies show that financial reform develops financial system by improving banking industry's competitiveness, mobilization of savings, and allocation of efficiency whereby achieving economic growth (Besanko and Thakor, 1992; Claessens and Laeven, 2004), there are limited studies those indicate financial reforms are disruptive and increases the vulnerability of the financial system (Rajan, 1992; Allen and Gale, 2000).

Literatures analyze several aspects of banking sector reforms and show its consequences in different countries. Khan and Aftab (1994) reviewed the effect of denationalization and privatization aspects of financial reforms in Pakistan. They conclude that denationalization of banks improved performance of these banks in terms of growth of assets, recovery of loans and ratio of bad loans.

Impact of banking sector reforms to the fiscal and monetary stability of many transitional economies was assessed by Feldman and Wagnar (2002) and they observed that the success of reforms significantly contributes to the fiscal and monetary stability.

Relationship between reform and bank efficiency was also examined by $\mathrm{Fu}$ and Heffernan (2008). They studied the performance of Chinese banking sector, and reviewed the reforms and their influences on the ROE, ROA and NIM. They found a significant relationship between profitability and reform. 
Brownbridge and Gockel (n.d.) examined necessity of banking sector reforms in Ghana in the 1980s and evaluated its impact. They concluded that while the reforms have brought about improvements in the banking system, banks are now more prudently managed and supervised.

One of the most important implications of technological advancement in banking is that it makes distant customers come closer (Howcroft \& Durkin, 2003). Majority of banks are planning to introduce ICT for integration of banking service and new financial service, which will play a vital role in bringing efficiency in financial sector (Raihan, 2001). Chandrasekhar and Sonar (2008) depicted that banks will reap the benefits of IT truly and totally, if and only if they pay adequate attention to technological progress as well as efficiencies on the input and output sides (Ali, 2010). Technology enables the bankers to create and recreate innovative services at lowest cost possible to ensure convenience to their customers. Lynch (1996) described technological benefit in two ways; firstly, it reduces the cost of production of financial services and secondly, it reduces the cost of delivery of the services to the customers. Technology maintains a lower cost by covering huge population of certain area at a time, which is virtually impossible through manual branch networking (Huda, Chisty and Rashid, 2007). But new technologies are not easy to implement. Howard and Moore (1982) reported that consumers must be aware of the new brand before adoption. Therefore it is an important factor that the banks have to create awareness on technology based banking to the consumers that depict a new trend in the development of banking industry.

\section{Banking: Trends and Changes}

At the beginning of the 21 st century, the biggest banks in the industrial world have become complex financial organizations that offer a wide variety of services to international markets and control billions of dollars in cash and assets. Supported by the latest technology, banks are working to identify new business niches, to develop customized services, to implement innovative strategies and to capture new market opportunities. With further globalization, consolidation, deregulation and diversification of the financial industry, the banking sector will become even more complex.

Although, the banking industry does not operate in the same manner all over the world, most bankers think about corporate clients in terms of the following:

Commercial banking - banking that covers services such as cash management (money transfers, payroll services, bank reconcilement), credit services (asset-based financing, lines of credits, commercial loans or commercial real estate loans), deposit services (checking or savings account services) and foreign exchange;

Investment banking - banking that covers an array of services from asset securitization, coverage of mergers, acquisitions and corporate restructuring to securities underwriting, equity private placements and placements of debt securities with institutional investors.

Over the past decade there has been an increasing convergence between the activities of investment and commercial banks, because of the deregulation of the financial sector. Today, some investment and commercial banking institutions compete directly in money market operations, private placements, project finance, bonds underwriting and financial advisory work. Furthermore, the modern banking industry has brought greater business diversification. Some banks in the industrialized world are entering into investments, underwriting of securities, portfolio management and the insurance businesses. Taken together, these changes have made banks an even more important entity in the global business community.

Retail Banking has experienced large changes since decades. Now lets have a glance at the five trends that will have a major impact on Retail Banking and consider the seismic shift in strategy required to remain successful in 10 years time.

\subsection{Generation $Y$}

The offspring of the baby boomers are commonly known as Generation Y. Born between 1975 and 1990 they are radically different to their parents. The way they interact with each other and the corporate world is leading a shift in behavior in all generations. They are becoming increasingly wealthy with an average income of $£ 23,500$ in the UK and will contribute significantly to a bank's P\&L over the next decade or so. The Generation Ys are much more likely to purchase from the internet with $41 \%$ using online banking or mobile. Naturally liberal and interested in the green movement they will care about your brand and ethical values.

\subsection{Internet Mega Players}

The giants of the Internet are coming and there is no hiding their ultimate strategy. Apple sits on cash reserve of $\$ 100$ bn and are under pressure to invest in new markets. Google, Pay Pal and many others are dipping their toe into the water with payment and mobile wallet solutions. Banks will see their transactional income reduce rapidly as Near Field Communication (NFC) and other peer-to-peer payment services become the norm. When these companies achieve critical mass in this space they will move to other areas either via acquisition or innovation.

\subsection{Town Centers Are Evolving}

When walking down many traditional high streets it won't have escaped your notice that they are primarily populated by coffee houses, charity shops and banks. Many of these high streets will continue to decline and will be replaced by fewer, larger entertainment destinations. These areas will be a mix of leisure, retailing and housing. The average footprint of the facilities will be significantly larger than their high street equivalents and customers will expect an experience rather than a transaction. 


\subsection{Data}

Understanding your customer is key for future competitive advantage. Many of the challenger brands already have access to a much broader and deeper pool of customer data than just their financial interactions (e.g. Sainsbury Nectar and Tesco Clubcard). Properly integrated, these are powerful tools to better understand customers, generate sales, risk profile customers, and can inform the development of new products and solutions. To be successful, banks will need to move beyond their limited customer insight, to develop knowledge of their individual customers from channel interaction and social media.

\subsection{Commoditization}

Greater use of technology means financial services products are becoming increasingly transparent. This will support the increasing use of comparison websites and will impact the industry profoundly. It's worth considering the impact of commoditization on the general insurance industry and translate that to other products. Clearly, commoditization will not be applicable to all sales but a significant proportion of the market will be impacted. A bank's strategy and commitment to the market will dictate their success.

\section{Islamic Banking Trends}

\subsection{Islamic Banking - the Future of Arab Banking}

Since the early 1970's, Islamic Banking practices have been gaining popularity and showing steady growth at an astounding rate of $10-15 \%$ annually in recent years, despite the world-wide economic downturn. Islamic banks base all their rules and regulations on the Shariah law of Fiqh alMuamalat (rules of transactions).

Islamic banks are now located in over 51 countries around the world, including the United States, and there are over 300 institutions that qualify as Islamic Banking institutions. Islamic finance and investing institutions are the largest growing sector in this industry, growing at $25 \%$ in the year 2010 .

Acting in Accordance with Shariah Law in a New Age of Islamic Banking

One of the most distinguishing practices in Islamic banking is the lending of money interest-free. Shariah law prevents the charging of interest on lent money. To comply with these laws, Islamic bankers have designed many different programs that allow for the lending of money, making of bank profits and compliance with Shariah law. Some Islamic banks found in Asia, most notably Bangladesh, participate in micro-lending programs, but some banking regulators find that this practice is not in accordance with Shariah law.

Push for Common Regulations in Arab Banking

Currently there are no rules regulating Islamic banking. While many organizations have been formed, such as the Union of Arab Banks, MENASA and the World Islamic Banking Conference, to address regulation issues, there are no set rules and regulations in place.
At a recent meeting of MENASA (Middle East North Africa South Asia) bankers a call was put forward to enact common banking regulations that will encompass all Islamic banking practices. It was stated that implementing a standardized form of processes, supervision and regulations among all Arab banks will allow for superior economic growth. It was also stated that the current economic crisis that the world is facing is even a stronger reason for these concessions.

As world banks implement more stringent regulations on banking practices and investments the Arab banking system may suffer due to its inability to be compatible amongst itself was the theme to this latest conference. Leaders agreed, but have yet to implement any industry wide changes to the system.

At this latest gathering of bankers it was stated that a failure to become a system that works well together will cause hardship in the Arab region. Economic development, infrastructure and all facets of industry could be directly affected by the inability of banks to all comply to one set Of regulations.

The World Islamic Banking Conference held in Asia at the beginning of June 2010 had similar opinions voiced during their seminars. This is the first time the World Islamic Banking Conference held a conference in Asia. The WIBC holds its regular conference in Bahrain in November of each year, and has done so for the past 17 consecutive years. The recent Union of Arab Banks conference had similar debate at their recent conference. The Union, a leader in information regarding Islamic banking practices encourages the development of a single set of laws for Islamic banking practices to ensure that Sharia law is obeyed.

The Fast Paced Future of Islamic Banking

With Islamic banking and investing growing at such an expediential rate is easy to understand why one set of regulations is necessary. It is estimated that nearly 200 billion dollars a day transact through Islamic banking, a considerable amount for such a new industry.

With an estimated 2 billion Muslims world wide it is easy to see that there is a huge potential for growth in this industry. A single set of regulations guiding this industry is a surefire way to ensure the continued growth of the industry as well as stability in the regions they serve.

\subsection{Origin of Islamic Banks in Bangladesh}

In August 1974, Bangladesh signed the charter of Islamic Development Bank and committed itself to reorganize its economic and financial system as per Islamic Shariah.

In 1978, Bangladesh government subscribed recommendation of Islamic Foreign Minister's conference held in Senegal regarding systematic efforts to establish Islamic banks in the member countries gradually.

In 1979, Mohammad Mohsin, the then Ambassador of Bangladesh in the UAE addressed a letter to the Foreign Secretary recommending establishment of an Islamic bank in Bangladesh in line with the Dubai Islamic Bank.

In 1980, Pro. ShamsulHuq, the then Foreign Minister, 
proposed that steps should be taken for development of an Islamic international banking system throughout the member countries in the Foreign Minister's conference held in Pakistan.

Earlier in November 1980, Bangladesh Bank, the country’s Central Bank, sent a representative to study the working of several Islamic banks abroad and this very year an international seminar on Islamic banking held in Dhaka was inaugurated by the Governor of Bangladesh Bank and he urged the participants to come forward to early introduction of an Islamic bank in Bangladesh.

In January 1981, the then President of the People's Republic of Bangladesh while addressing the $3^{\text {rd }}$ Islamic Summit Conference held at Makkah and Taif suggested: "The Islamic countries should develop a separate banking system of their own in order to facilitate their trade and commerce."

In November 1982, a delegation of IDB visited Bangladesh and showed keen interest to participate in establishing a joint venture Islamic Bank in the private sector. They found a lot of work had already been done and Islamic banking was in a ready form for immediate introduction. Two professional bodies Islamic Economics Research Bureau (IERB) and Bangladesh Islamic Bankers Association (BIBA) made significant contributions towards introduction of Islamic banking in the country.

At last, the long drawn struggle to establish an Islamic bank in Bangladesh became a reality and Islami Bank Bangladesh Limited was founded on $30^{\text {th }}$ March, 1983 in which 19 Bangladeshi national, 4 Bangladeshi institutions and 11 banks, financial institutions and government bodies of the Middle East and Europe including IDB and two eminent personalities of the Kingdom of Saudi Arabia joined hands to make the dream a reality.

In 1987, Al Baraka Bank Ltd. (now reorganized as The Oriental Bank) was established

In 1995, Al Arafah Islami Bank and Social Investment Bank Ltd. were established.

Shamil Bank of Bahrain (Islamic Bankers) has started its operation in 1997

Shahjalal Islami Bank Ltd. was established in 2001

From July, 2004 Exim Bank Ltd. converted its entire banking operation into Islamic Banking.

Nine conventional banks namely Prime Bank Ltd., Dhaka Bank Ltd., South East Bank Ltd. Premier Bank Ltd., City Bank Ltd., Jamuna Bank Ltd., First Security Bank Ltd Arab Bangladesh Bank Ltd., Bank Asia Ltd. Standard Chartered Bank and the HSBC have so far established Islamic Banking branches in some major cities.

\section{Electronic Banking- Emergence and Changes}

Electronic distribution channels provide alternatives for faster delivery of banking services to a wider range of customers (Kaleem and Ahmad, 2008). E-banking is the newest delivery channel of banking services. The definition of e-banking varies amongstresearchers partially because ebanking refers to several types of services through which a bank's customers can request information and carry out most retail banking services via computer, television or mobile phone (Mols, 1998; Sathye, 1999). E-banking can also be defined as a variety of the following platforms:

- internet banking (or online banking)

- telephone banking

- TV-based banking

- mobile phone banking

- PC banking (or offline banking) (Kolodinsky et al., 2004).

Most of the consumers who start banking online do it because they need to pay bills frequently and would like to do it with minimum effort. Besides that, people use the internet banking to keep an eye on their money matters, view their account balance and check receiving payments from other parties. E-banking technologies can be classified as either 'passive' or 'active' (Kolodinsky et al., 2004). Passive technologies such as direct deposit do not require behavioural changes on the part of the consumer. These innovations are therefore more easily spread to the mainstream. Active technologies on the other hand, require new behaviour and are therefore more challenging to propagate (Servon and Kaestner, 2008). E-banking requires perhaps the most consumer involvement, as it requires the consumer to maintain and regularly interact with additional technology such as a computer and internet connection (Kolodinsky et al., 2004).

\subsection{Generation of Electronic Banking Back-Office Front-Office}

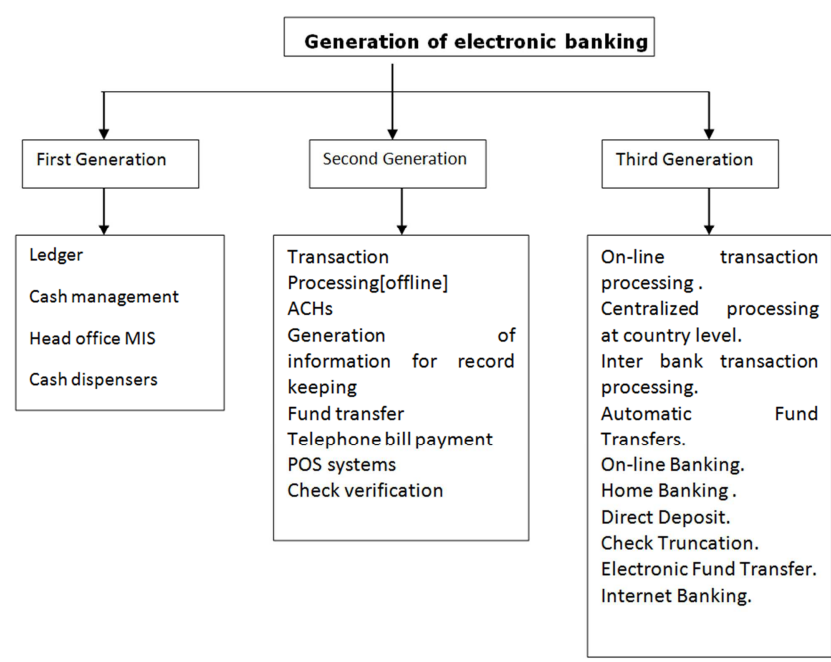

Figure 1. At glance view of generation of E-Banking in Bangladesh.

\subsection{Current Issues of E-banking}

There are several major challenges and issues facing the ebanking industry today.

First, and perhaps most important is the security concern (Feinman et al., 1999; Ziqi and Michael, 2003). Customers 
are certainly concerned of giving their bank account information online or paying an invoice through internet.

Another challenge facing e-banking industry and the ebusiness in general is the quality of delivery serviceincluding both delivery speed (i.e., short advance time required in ordering) and delivery reliability (i.e., delivery of items/services on time) (Furst et al., 2000), which caused many e-business failures in the earlier dot.com era. Limited online payment options have resulted in many customers to drop out in the last stage of the purchasing process due to dissatisfaction and inconvenience.

Finally, the issue of customer unfamiliarity with the internet, which is prominent among senior citizens, has recently caught some attention, because these customers believe that they are left at a disadvantageous position and become very reluctant in doing business online (Yang et al., 2007).

\section{Banking Sector Reform in Bangladesh}

Reform is not a one-shot exercise, but a dynamic socioeconomic process. Banking sector reform is also not an exception to this. During the 1970s and 1980s, there had been intense debate in Bangladesh on the need and rationale for financial sector reform. Contrastingly, one does not observe now-a-days any fundamental or conceptual objection to the objectives of reform, though there might be varying perspectives regarding its pace, sequencing, timing etc.

Initiatives to reform the financial sector in Bangladesh may be traced back to the beginning of the 1980s when the denationalisation of the Uttara Bank and Pubali Bank took place and a number of new private commercial banks (PCBs) were given licences. The Money, Banking and Credit Commission was constituted in mid-1980s to define the scope and modalities of the early phase of the reform.

Financial sector reform started in an intensive way in the beginning of the 1990s under the Financial Sector Adjustment Credit (FSAC) which Bangladesh contracted with the World Bank. Though the Financial Sector Reform Program (FSRP) ended in mid-1990s, yet the reform measures were continued to be pursued.

After the expiry of FSRP/TA in 1996, the Government of Bangladesh (GOB) formed a Bank Reform Committee (BRC), which submitted its recommendations in 1999. While the then government partially acted on some of the recommendations of the $\mathrm{BRC}$, a large part of them remain unaddressed. During the run-up to the last national elections, CPD launched a Task Force on Financial Sector Reform which prepared a set of recommendations for consideration by the newly elected government. The new incumbent government, after assuming the responsibility, has undertaken a number of measures for improving the performance of the financial sector.

\subsection{Reasons Behind Banking Sector Reform in Bangladesh}

Due to low interest rate, distortion in resource allocation, low rate of savings leading to financial disintermediation up to mid 1980, the banking sector was characterized by a "financially repressed" regime and the financial sector was being used to service the need of the Govt. sector and a few business houses with concomitant consequence of trivial financial system. Financial reform occurred due to following reasons:

The loanable fund at the disposal of the banks was disbursed mostly in publicly directed sectors without commercial consideration. The internal control system of commercial banks was weak, the books of accounts did never reflect the actual financial health of the banks, the quality of assets of the banks was never evaluated on strict accounting principles, the MIS was virtually non-existent in the banking sector, profitability and liquidity aspect of portfolio management was unfamiliar concept among the management personnel, the elements of capital adequacy for banking operation were never given due weightage.

The pervasive weakness in the money market was observed in the capital market also. The only stock exchange of the country namely the Dhaka Stock Exchange was almost inoperative with only a few enlisted companies. Bangladesh shilpa Bank (BSB) \& Bangladesh Shilpa Rin Shangstha (BSRS) were financing projects out of loans from IDA, ADB credit lines to projects which were hardly appraised from the point of view of cost benefit analysis.

The need for overhauling of the financial sector was felt in order to bring about structural, institutional and policy changes in the fragile financial sector, and for this purpose a National commission of Money, Banking and credit was constituted in 1984. The commission submitted reports to the Govt. in 1986 identifying the problem areas in our financial sector with specific recommendations to bring about the structural, institutional, policy and legal reforms.

The crises of 1997 which began in the foreign exchange market and spread quickly through the banking sector of most of the Asian countries challenged the slow moving style of reform.

\subsection{Reform Actions - A Chronology}

a. Institutional Reform

Privatization of Banks: The first reform program in the financial sector of Bangladesh was initiated in 1982, when the government decided to allow the operation of local private banks and denationalize two out of six nationalized commercial banks (NCBs). The main reason for allowing local private banks was the desire on the part of the government to demonstrate its commitments to encourage the private sector and to create competition in the baking sector. It transpires from various studies that denationalization and privatization process could not generate the expected results because of absence of strict supervision coupled with rigid economic regulations on the part of the Bangladesh Bank. Though in some respects quality of customers' services improved, yet the overall banking efficiency, specially in the context of credit management was observed to have deteriorated. This policy has been aimed at bringing about efficiency through competition in the banking sector and 
gradual privatization of the 4 NCBs which still hold $60 \%$ of the total bank deposits. At present our banking sector has accommodated 17 private banks including 4 Islamic Banks and 13 foreign banks in addition to 4 nationalized banks and 5 specialized banks. Under the present policy of liberalization, scope exists for operation of more indigenous private sector banks and foreign owned banks keeping a very cautious watch over the overall performance of the economy in the years to come. With operation of 39 banks having about 6000 branches all over the country, banking services have been brought nearer to people.

Interest Rate Liberalization: In January 1990, in place of arbitrarily fixed interest rate, Bangladesh Bank introduced a flexible market oriented interest rate structure. It was a major policy change introduced in a key policy variable was in the area of interest rate policy. Lending rate bands were determined on the basis of shadow lending rates and deposit rate bands were determined taking into consideration 'the expected rate of inflation and a positive real return for savers. Interest rate bands were abolished except for export, agriculture and small \& cottage industries. At present, banks are free to fix up their deposit rates on the basis of market forces. It may be noted here that the financial sector reform measures have adversely affected the rural deposit mobilization and rural credit flow from the conventional Government owned institutional sources, but their dormant inefficient and ineffective role facilitated the growth of innovative rural credit institutions like Grameen Bank, BRAC, PROSHIKA, ASA, Ansar-VDP Bank, Swanirvar Program, PKSF and its hundreds of partners organizations, i.e. NGOs.

Credit Information Bureau: Credit Information Bureau (CIB) has been created in Bangladesh Bank in December, 1992 to restore and strengthen the credit discipline and to provide adequate reliable credit information among banks to facilitate loan sanctioning, and its operation started from 1993. The main objectives of CIB are as follows:

1. Collecting all credit information of the borrowers having outstanding loan of Tk. 10.00 lacs and above from all the banks and non-banking financial institutions.

2. Providing credit information to all banks and financial institutions to facilitate loan sanctioning, renewal and rescheduling from the computer database.

3. Preparing credit reports for using the Government and international financial institution and to provide relevant data on bank credit for research and studies.

4. Preparing and providing Credit Risk rating of the borrowers to banks.

Loan Classification Guideline: Before introducing updated loan classification guidelines in 1989 by Bangladesh Bank, the commercial banks did not follow any norm to classify their bad and non-performing loans. Banks did not keep provision for their poor quality assets. Hence there was huge provision short-fall and capital inadequacy of NCBs took a serious shape for which Govt. came forward by issuing bonds to salvage the NCB s. As on 30 June'97 NCBs had actual capital of 1306 crore with a shortfall of 524.39 crore. The private sector banks as on 30/06197 had a shortfall of 79.37 crore. As far as classified loan is concerned as on $31 / 12 / 97$ NCBs had $29.85 \%$ of their loans classified as against $23.02 \%$ for private banks' and the required provision was 4058.97 crore as against actual provision 1836.51 crore with a shortfall of 2222.46 crore. The corresponding figure of private banks' requirements was 1885.23 crore against which they maintained 980.97 crore leaving shortfall of 909.00 crore. Bangladesh Bank is constantly monitoring the bank's performance and improvement on the issue of provision and capital shortfall.

Capital Adequacy Requirement: In order to safeguard the interest of depositors and bring about a universally accepted status of our banking sector, risk weighted capital adequacy requirement has been introduced from January 1996 and it is now mandatory for the banks to maintain $10 \%$ of the assets in risk weighted manner since 1996. Banks are strictly advised to maintain the adequacy element of capital and Bangladesh Bank is constantly monitoring the status of commercial banks in this regard.

Legal Reform:

Bank Companies Ordinance: Banking Companies were being guided under Bank Companies Ordinance, 1962 of erstwhile Pakistan which became outdated to cater to the needs of private banks \& NCBs in changed circumstances. It was replaced by Bank Companies Act, 1991 which provides with wide range of power to Bangladesh Bank to deal with banking sectors' monitoring, regulation and supervision.

The Financial Institutions Act, 1993: This act was formulated to deal with the affairs of Non-Banking Financial Institutions (NBFIs). As per provision of this Act, cautious approach is taken to issue license for new NBFIs and monitoring and supervision of the existing NBFIs are being made to ensure their sound operation.

The Bankruptcy Act: It was enacted in 1997 and 2 Bankruptcy Courts have been set up in the commercial areas of Dhaka and Chittagong and will be in operation within a month to deal with delinquent big defaulters. Adequate numbers of financial loan courts have also been created to deal exclusively with bank loan defaulters.

b. Reforms in Fiscal Policy:

To reduce overall deficit in the budget and to attain GDP growth rate and increase in the rate of investment to around $18 \%-20 \%$ within year 2000 increased domestic resource mobilization is one of the important fiscal policy objectives of the Govt.

Under fiscal reforms, the objective was to strengthen and streamline revenue by broadening tax base, rationalizing tax structure and improving tax administration. 
Table 1. Bank Wise Growth Rate of Deposits (Taka in crore).

\begin{tabular}{|c|c|c|c|c|c|c|c|}
\hline End of Period & NCBs & Growth rate & Private & Growth rate & Others $^{*}$ & Total & Growth rate \\
\hline $1985-86$ & 6974.04 & - & 2139.68 & - & 1270.78 & 10384.5 & - \\
\hline $1986-87$ & 8030.31 & 15.15 & 2722.1 & 27.22 & 1645.69 & 12398.1 & 19.39 \\
\hline $1987-88$ & 8894.61 & 10.76 & 3292.15 & 20.94 & 1806.24 & 13993 & 12.86 \\
\hline $1988-89$ & 10276.6 & 15.54 & 4035 & 22.56 & 2149.97 & 16461.57 & 17.64 \\
\hline $1989-90$ & 11901 & 15.81 & 4894.86 & 21.31 & 2313.52 & 19109.38 & 16.08 \\
\hline $1990-91$ & 13087.3 & 9.97 & 5774.4 & 17.97 & 2530.55 & 21392.25 & 11.95 \\
\hline $1991-92$ & 15352.1 & 17.31 & 6266.47 & 8.52 & 2834.85 & 24453.42 & 14.31 \\
\hline $1992-93$ & 16815.7 & 9.53 & 7681.5 & 22.58 & 2558.3 & 27055.5 & 10.64 \\
\hline $1993-94$ & 19371.2 & 15.20 & 8436.4 & 9.83 & 3179.4 & 30987 & 14.53 \\
\hline $1994-95$ & 21807.4 & 12.58 & 9957.05 & 18.02 & 3882.73 & 35647.18 & 15.04 \\
\hline $1995-96$ & 23665.6 & 8.52 & 10738.75 & 7.85 & 4162.93 & 38567.28 & 8.19 \\
\hline $1996-97$ & 25939.8 & 9.61 & 12136.36 & 13.01 & 4976.28 & 43052.42 & 11.63 \\
\hline
\end{tabular}

* Specialized and Foreign Banks

Source: Bangladesh bank Bulletin, April-June, 1997

Table 2. Sector-wise Bank Credit Position. From December 1995 to December 1997 (Taka in crore).

\begin{tabular}{|c|c|c|c|c|c|c|c|c|c|c|c|c|c|}
\hline $\begin{array}{l}\text { SI } \\
\text { No. }\end{array}$ & Sector & $\begin{array}{l}\text { December } \\
\text { '95 Total } \\
\text { Outstd. }\end{array}$ & $\%$ & Overdue & $\%$ & $\begin{array}{l}\text { December } \\
\text { '96 Total } \\
\text { Outstd. }\end{array}$ & $\%$ & Overdue & $\%$ & $\begin{array}{l}\text { December } \\
\text { '97 Total } \\
\text { Outstd. }\end{array}$ & $\%$ & Overdue & $\%$ \\
\hline 1 & Agriculture Credit & 5472.39 & $15 \%$ & 3783.57 & $27 \%$ & 5930.07 & $14 \%$ & 4376.61 & $25 \%$ & 6144.34 & $13 \%$ & 4390.38 & $23 \%$ \\
\hline 2 & $\begin{array}{l}\text { Large \& medium } \\
\text { Industries term } \\
\text { credit }\end{array}$ & 5448.49 & $15 \%$ & 2382.39 & $17 \%$ & 6580.44 & $15 \%$ & 2402.92 & $14 \%$ & 7693.78 & $16 \%$ & 2924.14 & $16 \%$ \\
\hline 3 & $\begin{array}{l}\text { Working Capital } \\
\text { Credit }\end{array}$ & 6889.75 & $19 \%$ & 1989.61 & $14 \%$ & 8574.68 & $20 \%$ & 2769.57 & $16 \%$ & 9239.22 & $19 \%$ & 3030.74 & $16 \%$ \\
\hline 4 & Export Credit & 1700.63 & $5 \%$ & 493.61 & $4 \%$ & 2169.88 & $5 \%$ & 552.91 & $3 \%$ & 2667.68 & $6 \%$ & 548.1 & $3 \%$ \\
\hline 5 & Commercial Credit & 7850.32 & $22 \%$ & 2769.31 & $20 \%$ & 10078.65 & $24 \%$ & 4113.54 & $24 \%$ & 12242.76 & $26 \%$ & 4329.74 & $23 \%$ \\
\hline 6 & $\begin{array}{l}\text { Small and Cottage } \\
\text { Industries Term } \\
\text { Credit }\end{array}$ & 1398.27 & $4 \%$ & 707.06 & $5 \%$ & 1730.13 & $4 \%$ & 883.15 & $5 \%$ & 2363.36 & $5 \%$ & 1324.63 & $7 \%$ \\
\hline \multirow[t]{2}{*}{7} & Others & 6862.43 & $19 \%$ & 1674.98 & $12 \%$ & 7819.75 & $18 \%$ & 2398.16 & $14 \%$ & 7251.58 & $15 \%$ & 2181.02 & $12 \%$ \\
\hline & Total & 35622.28 & & 13800.53 & $39 \%$ & 42883.6 & & 17496.86 & $41 \%$ & 47602.72 & & 18728.75 & $39 \%$ \\
\hline
\end{tabular}

Source: Scheduled Bank Statistics, Bangladesh Bank.

\subsection{Recent Policy Measures}

A) Reduction of Bank Rate and Lending Rate: Immediately after the present government took office in September, 2001, The Bangladesh Bank reduced the bank rate with a view to decreasing the lending rate and, consequently, increase the volume of lending. It has been observed that following the reduction of bank rate, most of the NCBs and the PCBs have reduced their lending rates more or less proportionately. As a result, the actual spread for the banks was supposed to decline. However the actual spread of the NCBs is not expected to decline because of their simultaneous reduction of deposit rates. However, the spread has declined for the PCBs. This is also true for the foreign commercial banks (FCBs).

In fine, the bank rate driven lending rate reduction approach is going to have very limited results.

B) Linking Classified Loan Level to Large Loan Sanctioning: In January 2002, Bangladesh Bank has revised the "Large Loan Rules" with respect to classified loan of the banks. The new rule prescribes that the banks with net classified loan of up to five per cent will be allowed to sanction a maximum of 56 percent of the total loan and advances as "large loans". that is a loan deal with an amount above Taka 10 million.

The new rule is expected to contain the credit risks of a bank within a reasonable range, prohibit the tendency of concentrating bank resources in a few hands and encourage a bank to give loans to small and medium sized projects (SMEs) for diversified industrial development.

C) Rationalization/Merger of Loss Incurring Branches of NCBs and DFIs: For the matter of running the banks on commercial basis, the concerned authorities have decided to merge/rationalize continuously loss incurring branches of the NCBs and the DFIs. It has been decided that the branches which are incurring losses continuously for the last five years and having no potentiality of becoming profitable in future, will be merged with another nearby branch. At this moment, there are 806 branches (of the NCBs and DFIs) which are incurring losses continuously for the last five years.

D) Measures for Loan Recovery: Diverse factors have precipitated the loan default problem in Bangladesh: lack of loan screening skill, lack of supervision and accountability on the part of bank management Mellifluence of political and 
other vested group, high loan price, volatile economic environment, corruption and unethical activities on the part of concerned stakeholders etc.

For the matter of resolution of problem loans, CPD in 1997 and subsequently the BRC in 1999 have recommended to articulate and implement a sound "Recovery Policy" by the NCBs, form an Asset Management Company (AMC) and establish specialized loan work-out department in each bank. Very recently, the Ministry of Finance (along with the Bangladesh Bank, NCBs and DFIs) has initiated a move to set a guideline to write-off bad loans of the banking system. Possibly the process is yet to be completed. In the meantime, the Bangladesh Bank has announced a uniform incentive package for recovery of classified loans for the NCBs.

As a policy measure, incentive schemes for loan recovery should be thought of only as an interim/short term measure. In the medium term, the incentive schemes is fraught with "moral hazard" problem. To evolve a sustainable policy package in this respect the government may think of the proposals put forward by the BRC mentioned earlier.

\section{The Road Map Ahead}

The modern banking industry has brought greater business diversification. Some banks in the industrialized world are entering into investments, underwriting of securities, portfolio management and the insurance businesses. Taken together, these changes have made banks an even more important entity in the global business community. In case of reforms, a holistic strategic framework for the finance sector could include potential response initiatives that address targeted performance metrics and strategic results relating to growth and development, governance, sustainability, efficiency, reach, governmental presence and the enabling environment.

\section{References}

[1] Bank Porikroma, Bangladesh Bank.

[2] Recent trends and developments in e-banking in anunder developed nation - an empirical study.

[3] Trends in the banking industry.

[4] Allen, F. \& Gale, D. (2000). Comparing Financial Systems. Boston, MA: MIT press.
[5] Benhabib, J. \& Spiegel, M. M. (2000). The Role of Financial Development in Growth and Investment. Journal of Economic Growth, 5, 341-360.

[6] Besanko, D. \& Thakor, A. (1992). Banking Deregulation: Allocational consequences of relaxing entry barriers. Journal of Banking and Finance, 16, 909-932.

[7] Brownbridge, M., \& Gockel, A. F. (1996). The Impact of Financial Sector Policies on Banking in Ghana. Sussex: Institute of Development Studies.

[8] Burki, A. A., \& Niazi, G. S. K. (n. d.). Impact of Financial Reforms on Efficiency of State-owned, Private and Foreign Banks in Pakistan. CMER Working Paper No. 06-49, Lahore: Lahore University of Management Sciences. Retrieved from http://www.eastasiaforum.org/testing/eaber/sites/default/files/d ocuments/LUMS_Burki_2006.pdf.

[9] Caprio, G. \& Klingebiel, D. (1999). Episodes of systematic and borderline financial distress. USA: The World Bank.

[10] Claessens, S. \& Laeven, L. (2004). What drives bank competition? Some international evidence. Journal of Money, Credit and Banking, 36, 563-584.

[11] Cooray, A. (2003). An Evaluation of the Financial Reform Process in Sri Lanka. Sri Lanka Economic Journal, 4 (1), 123.

[12] Dunham, D. \& Kelegama, S. (1996). Economic Liberalisation and Structural Reforms: The experience of Sri Lanka 1977-93. New Delhi, India: New Age International Publishers.

[13] Golubović, S., \& Golubović, N. (2005). Financial Sector Reform in the Balkan Countries in transition. Facta Universitatis Economics and Organization. 2 (3), 229-236.

[14] Heffernan S. A., \& Fu, X. (2009). The Effects of Reform on China's Bank Structure and Performance. Journal of Banking and Finance. 33 (1), 39-52.

[15] Levine, R. (2005). Finance and Growth: Theory and Evidence. In P. Aghion \& S. Durlauf (Ed.), Handbook of Economic Growth (pp. 865-934). Netherlands: Elsevier B. V.

[16] Lucas, R. E. (1988). On the mechanics of economic development. Journal of Monetary Economics, 22 (1), 3-42.

[17] McKinnon, R. I. (1973). Money and Capital in Economic Development. Washington D. C.: The Brookings Institution.

[18] Rajan, R. (1992). Insider and Outsiders, the Choice between Informed and Arm's-Length Debt. Journal of Finance, 47, 1367-1400.

[19] Reddy, Y. V. (2005). Governor's speech. Bankers' Institutions, Karachi, May 2005. 